\title{
När olikhet blir problem: handikappforskning, kontext och social interaktion
}

\author{
LARS-CHRISTER HYDÉN, CLAES NILHOLM \\ \& KRISTINA KARLSSON
}

\begin{abstract}
I artikeln argumenterar författarna för försök att inom handkappforskningen gå utöver traditioner av att den medicinska kroppsuppfattningen är ett bärande element $i$ analyser av det sociala.
\end{abstract}

\section{Inledning}

Inom handikappforskningen finns ett behov av ett socialt perspektiv på vad som på engelska kallas "impairments" - vad vi på svenska brukar referera till som skada eller sjukdom. Det är ett argument som framförs av de båda brittiska handikappforskarna Bill Hughes och Kevin Paterson i två artiklar (Hughes \& Paterson, 1997; Paterson \& Hughes, 1999). De vill utveckla vad de kallar "a sociology of impairment"

Lars-Christer Hydén är professor vid tema Kommunikation, Linköpings universitet. Han har ett speciellt fokus på hur språk och berättelser används för att artikulera och kommunicera sjukdom, sociala problem och funktionshinder.

Claes Nilholm är docent i tema Kommunikation, Linköpings universitet, samt arbetar som lektor i pedagogik vid Örebro Universitet. Han har skrivit en rad vetenskapliga arbeten om barns lärande och socialisation samt om kommunikation och funktionshinder. som problematiserar "not the performance of the bodies, but the 'protocols' of intercorporeality which provide the basis for judgements about performance» (Hughes \& Paterson, 1997).

Även om Hughes och Paterson skriver i ett brittiskt sammanhang, menar vi att deras resonemang har relevans för svensk (och skandinavisk) handikappforskning. Precis som Hughes och Paterson tror vi att det finns risker med att handikappforskningen fokuserar alltför mycket både på handikappbegreppets normativa, ideologiska och politiska sidor, och på implementeringen av handikappolitiska reformer. Det är något som riskerar leda till att det bak-

Kristina Karlsson är doktorand vid tema Kommunikation, Linköpings universitet. Fil mag i Personal- och arbetsvetenskap med psykologisk inriktning samt ytterligare studier i Folkhälsovetenskap. I avhandlingsprojektet studeras hur den »brukarcentrerade» ideologin omsätts i praktiken.

Hydén, Nilholm \& Karlsson: När olikhet blir problem: Handikappforskning, kontext och social ... 
vägen smyger sig in en individualiserad och medikaliserad syn på funktionshinder och handikapp. Att rikta ett kritiskt sökljus mot "impairments« är speciellt viktigt eftersom det finns ett starkt ideologiskt tryck att tolka och förstå just "impairments» som både individuellt och kroppsligt givna egenskaper.

I likhet med Hughes och Paterson vill vi argumentera för att det är viktigt att ur ett kritiskt forskningsperspektiv belysa den problematiska kroppen och det förkroppsligade sociala handlandet. Det finns dock anledning att gå ett steg vidare i linje med Hughes och Patersons resonemang och undersöka på vilket sätt kroppar kommer att framstå som problematiska i olika sociala kontexter. En handikappforskning som riktar fokus mot hur vissa mänskliga kroppsliga och andra olikheter etableras som funktionshinder, och hur dessa olikheter levs, har mycket att vinna teoretiskt och metodologiskt på att knyta an till forskningen kring social interaktion och kommunikation i form av mikrosociologi som exempelvis etnometodologi och den goffmanska traditionen. Även om andra har uttryckt detta forskningsbehov tidigare, kan vi konstatera att det finns förhållandevis lite empirisk forskning genomförd med denna inriktning.

Vi har ett dubbelt syfte med denna artikel. För det första att argumentera för en inriktning av handikappforskning mot studier och detaljerade analyser av hur svårigheter och problem uppkommer och identifieras som exempel på »impairments» och funktionshinder i den sociala interaktionen i olika kontexter. Och för det andra att argumentera för ett forskningsperspek- tiv som inte reproducerar den carteanska kropp-själ dualismen, utan där hänsyn tas till kroppen som situerad i interaktionella sammanhang. Vi menar alltså att det är nödvändigt att studera situerad interaktion mellan människor med "levda kroppar" (för att använda Merleau-Ponty's begrepp). Därmed vill vi försöka gå utöver traditioner där den medicinska kroppsuppfattningen har kommit att bli ett bärande element i analyser av det sociala.

Inledningsvis kommer vi att ur en samhällsvetenskaplig synvinkel problematisera biologiserandet av kroppen inom handikappforskningen. Därefter presenterar vi några grundläggande begrepp som kan användas som utgångspunkt för ett samhällsvetenskapligt perspektiv på »impairments" och "funktionshinder". Därefter illustrerar vi med hjälp av tidigare forskning just betydelsen av att studera kroppen som situerad och i ett interaktivt perspektiv. Vi har här valt exempel med personer som just har svårigheter med att använda verbala medel, eftersom detta tydliggör vår poäng vad gäller betydelsen av att se kroppen som situerad.

\section{Den biologiserade kroppen}

Hughes och Paterson (1997; Paterson \& Hughes, 1999) vänder sig mot tendensen bland i synnerhet brittiska handikappforskare, att utifrån den så kallade sociala modellen av handikapp, betrakta "impairments» som något biologiskt, medicinskt eller kroppsligt givet. Istället menar Hughes och Paterson att det ur ett kritiskt samhällsvetenskapligt perspektiv finns all anledning att undersöka och belysa hur kroppar och 
delar av det förkroppsligade handlandet kan komma att ses och uppfattas som en skada eller sjukdom och kodifieras som exempelvis "impairment». Det finns också en tendens menar de, att betrakta funktionshinder ("disability") enbart som ett handikappolitiskt fenomen, där den enskilda individen endast är aktuell som någon som utsätts för förtryck eller diskriminering. Det är en kritik som i många avseenden knyter an till Söders (1995) kritik av delar av handikappforskningen i Sverige. Hughes och Paterson befarar att vi därmed inte ser att handikapp är förkroppsligat, "embodied", och en del av en levd kropp, vilket innebär att den enskilde individen, hennes kropp och upplevelser, riskerar att lämnas utanför analysen (jfr också Marks, 1999).

Mer speciellt menar Hughes och Paterson (1997; Paterson \& Hughes, 1999) att den så kallade sociala modellens synsätt på "impairments» bygger på ett för-givettagande av kroppen och dess funktioner. Kroppen blir därmed en materiell entitet som helt är underkastad biologins lagar. Vad en kropp är, och hur kroppen fungerar, är därmed något som ligger helt utanför den sociala modellens intresse. Istället riktar man all uppmärksamhet mot de sociala konsekvenserna av skadan eller sjukdomen och de handikappolitiska aspekterna. Därmed menar Hughes och Paterson (1997) att handikappforskare kommer att reproducera den klassiska cartesianska kroppsuppfattningen, med kroppen som skild från "själen" och de sociala förhållandena.

Problemet med den sociala modellen blir därmed att den lämnar forskning kring "impairments« utanför den samhällsvetenskapliga sfären, och överlämnar den åt i första hand den medicinska forskningen. Paterson och Hughes (1999) menar att det finns mycket inom den framväxande samhällsvetenskapliga forskningen och intresset kring kroppen som skulle kunna utnyttjas inom handikappforskningen. Speciellt nämner de den poststrukturalistiska diskussionen av kroppen så som den företräds av exempelvis Foucault (1973) och Bryan Turner (1992), den fenomenologiska traditionen i form av exempelvis Merleau-Ponty (1962) och Csordas (1994), eller etnometodologer som Robillard (1999) och Goode (1995).

Vad gäller att visa på vad en sådan forskningsinriktning kan innebära för handikappforskningen blir Paterson och Hughes (1999) enligt vår mening vaga. Utifrån de exempel som de diskuterar finns det en risk för att en sådan forskning i första hand kan komma att handla om att beskriva och förstå enskilda individer och deras upplevelser, snarare än människor i samspel med varandra i olika konkreta, sociala kontexter. Vi återkommer till denna diskussion senare när vi diskuterar konkreta studier av social interaktion. Först vill vi presentera hur vi tänker oss att konkreta analyser av interaktion skulle kunna knytas till mer övergripande sociala förändringar och ses i relation till individers livsförlopp.

\section{Två utgångspunkter}

Ett sätt att närma sig sådant socialt handlande och samspel som vi tenderar att uppfatta och definiera i termer av wimpairment", och senare som ett funktionshinder, är att rikta fokus mot sådana situationer där något kommer att framstå som ett prak-

Hydén, Nilholm \& Karlsson: När olikhet blir problem: Handikappforskning, kontext och social ... 
tiskt och påtagligt problem i det vardagliga livet. Med problem menar vi när en eller flera personer i hemmiljö eller i situationer som skolan identifierar svårigheter som uppfattas höra samman med en individs förmåga att praktiskt och socialt fungera i enlighet med de situerade förväntningarna och normerna. Av speciellt intresse är då hur detta problem organiseras, definieras, kategoriseras och hanteras, och inte minst under vilka omständigheter som det blir föremål för professionellas intresse och insatser. En sådan problemidentifieringsprocess kan urskiljas både i ett samhälleligt, historiskt perspektiv där framväxandet av olika professioner skett i utifrån vad som kommit att identifieras som sociala problem; och i individers livsförlopp, det vill säga sociala situationer där individer kommer att betraktas som problematiska.

Vi föreslår i förlängningen av detta resonomang en utgångspunkt för en handikappforskning inriktad mot social interaktion och kommunikation, som avser att fylla två grundläggande kriterier. För det första bör den inte förutsätta några givna definitioner av vad funktionshinder och handikapp är (eller bör vara), förutom idén om mänsklig olikhet. För det andra skall den kunna fungera som ett analytiskt ramverk för studier av olikhetens transformationer över tid och olika sociala sammanhang, både historiskt och under livsförloppet. Därmed kommer fokus inte i första hand att ligga på vad som traditionellt brukar kallas etiketteringsprocesser (labelling process), utan på hur vi i olika sociala sammanhang identifierar, beskriver och förhåller oss till problem - vad som alltså skulle kunna kallas problemdefinitions- och problemhanterings- processer. Tanken på problemhantering kommer från Ervin Goffman (1963) och den amerikanske sociologen Robert Emerson (Emerson, 1981; Emerson \& Messinger, 1977).

\section{Olikhet, problem och hantering}

Ett analytiskt och begreppsligt alternativ till »impairment« är begreppet olikhet. Det vill säga, tanken att alla människor är olika, såväl kroppsligt och psykologiskt som på en mängd andra sätt. Under olika sociala, kulturella och historiska sammanhang, kommer vissa typer av olikheter att lyftas fram eftersom de kommer att utgöra praktiska problem för människor, både i arbetslivet, skolan och privatsfären. Mänsklig olikhet är alltså i sig inte problematisk, det är första under vissa sociala och kulturella förutsättningar som olikheten tematiseras och utgör ett gemensamt uppmärksamhetsfokus.

Då vårt sociala samspel, vardagliga och institutionella liv i stor utsträckning bygger på standardiseringar, typifieringar och normaliseringar, kan olikheter skapa problem i konkreta sociala sammanhang. Av speciellt intresse är hur de problematiska olikheterna tematiseras i olika sammanhang som exempelvis skolan, där vissa typer av olikheter skapar påtagliga praktiska problem, något som exempelvis den amerikanske sociologen Hugh Mehan har observerat i ett flertal studier av barn som senare blir diagnosticerade som lågbegåvade (Mehan et al., 1986).

När vi har svårt att själva klara av att hantera problem inom ramarna för vardagen, 
tenderar vi att söka hjälp hos professionella problemhanteringsexperter, som exempelvis psykologer. När problem tematiseras blir de ofta också automatiskt föremål för försök till definition och därmed klassificeras de. Det kan ske genom att det tematiserade problemet blir föremål för någon form av diagnosticering av en expert. Exempel på sätt att klassificera problematiska olikheter är de systematiska prov och test som används inom BVC, förskolan och skolan för att konstatera i första hand normavvikelser och där det etablerats metoder för att klassificera identifierade problematiska olikheter.

Ett speciellt intressant drag i vissa typer av diagnostiska samtal som berör personer som på något sätt har identifierats såsom problematiskt olika, är att de har en evaluerande aspekt. Det vill säga, i dessa samtal finns ofta en strävan från den professionelle att på ett eller annat sätt försöka värdera exempelvis kompetensen hos den person som identifieras som problematisk. Flera forskare har i empiriska studier visat att i denna typ av samtal utnyttjar framför allt professionella en rad sociala och språkliga resurser för att kunna evaluera "eleven", "klienten" eller "patienten«: sätt att konstruera frågor och lämna alternativ, genom speciella markeringar genom upprepningar, genom perspektivtagande i frågandet, etc. (Se Duchan, Maxwell \& Kovarsky, 1999, för en översikt av denna typ av forskning.)

En viktig aspekt av att kategorisera ett problem är att klargöra vem som är problembärare (och vem som äger rätten att definiera det). Det reser frågor om hur själva kategoriseringen går till och hur vi aktivt använder oss av kategoriseringar $i$ olika sammanhang. Klassifikationer och kategorisering av personer får konsekvenser inte minst vad gäller deras sociala identitet. Det är något som är speciellt intressant $\mathrm{i}$ relation till hur professionella i exempelvis skolan utnyttjar och använder sig av etablerade kategorier, något som har diskuterats av många forskare.

Mehan har i en rad studier (Mehan et al., 1986; Mehan, 1992) visat hur skolan genom sitt sätt att hantera elever med vissa typer av klassrumsproblem. Det kan exempelvis ske genom att lärare kontaktar skolpsykologer som genomför test och senare deltager $i$ skolkonferenser och genom denna process kommer att definiera eleven och klassrumsproblemen som ett resultat av att eleven är "utvecklingsstörd" eller "lågbegåvad». För Mehan ligger fokus på de organiserande procedurer varigenom problem i klassrummet omvandlas till ett välkategoriserat och väldefinierat, och därmed organisatoriskt hanterbart, problem för skolans professionella, nämligen ett barn med en viss typ av funktionshinder.

På ett liknande sätt visar McDermott (1993) att vad som framstår som och kommer att uppfattas som ett intellektuellt funktionshinder i skolan, är avhängigt av hur bland annat det pedagogiska samspelet mellan elever organiseras. Vissa elever klarar skoluppgifter om de exempelvis får möjlighet att arbeta tillsammans med andra elever, medan de om de skall lösa uppgifterna på egen hand framstår som svagpresterande och lågbegåvade elever. Vad McDermott framhåller är att vilka elever som kommer att framstå som ett problem för läraren i klassrummet bland annat är beroende av hur den pedagogiska interaktionen organiseras. 
Vi kan konstatera att det i stor utsträckning saknas denna typ av studier vad gäller exempelvis den aktuella debatten kring så kallade bokstavsbarn, eller barn och ungdomar med neuropsykiatrisk problematik (ADHD, autism och Aspergers syndrom, etc.). Det finns få - om några - studier av samspelssituationer i skolan som ger en möjlighet att analysera och förstå de svårigheter och problem som uppenbarligen uppkommer för vissa barn i skolsituationen och hur dessa kommer att kategoriseras. Genom avsaknad av sådana studier lämnas också hela frågan om hur begrepp, teorier och föreställningar om denna typ av funktionshinder förhåller sig till vardagliga situationer och praktiken. Istället får vi en i första hand ideologisk diskussion kring de så kallade bokstavsbarnen.

Ett diagnosticerat problem blir föremål för ytterligare olika former av problemhantering, det vill säga de organiserade sociala processer varigenom vi försöker hantera de problematiska olikheterna både på ett övergripande samhälleligt plan och i termer av individers livsförlopp. Här kan bara nämnas de mer övergripande politiska och juridiska kontexter som på olika sätt försöker reglera vad som identifierats som problemområden. Det kan handla om statliga utredningar, socialstyrelsens riktlinjer, lagstiftning som LSS, och så vidare. Ibland tillskapas speciella institutionella kontexter för att hantera identifierade problem, såsom exempelvis särskolan för barn med utvecklingsstörning.

Sammanfattningsvis kan i princip tre olika typer av sociala sammanhang eller kontexter urskiljas för problemdefinition och problemhantering: (1) vardagliga kontexter där det tematiserade problemet inte nödvändigtvis behöver uppfattas på liknande sätt som det av experter klassificerade och diagnosticerade problemet; (2) institutionella kontexter som är speciellt skapade för problemdefinition och problemhantering; och (3) vad vi vill kalla reflexiva kontexter i vilka både relationerna mellan olika institutionella kontexter, arbetet med problemhanteringen och individens livssammanhang blir föremål för reflektion ofta i form av samtal med delaktighet av (helst) individen själv och representanter för de olika kontexterna.

\section{Kommunikation i den reflexiva kontexten}

I takt med att det moderna samhället blivit alltmer komplext $i$ den meningen att individer är delaktiga i en rad olika sociala sammanhang, så har koordineringen av de olika kontexterna kommit att utgöra ett "metaproblem". Inom exempelvis habiliteringen har det vuxit fram speciella forum där en av de främsta uppgifterna är att samordna individens olika kontexter. Ett annat exempel är skolans utvecklingssamtal. Det är ett exempel på vad vi ovan kallar reflexiva kontexter och vars främsta funktion är att koordinera individers livssammanhang.

Många forskare har argumenterat för att samhället idag inte i samma utsträckning som tidigare bygger på traditionella sociala roller med för-givet-tagna skyldigheter och rättigheter (se $\mathrm{t}$ ex Giddens, 1991; Gergen, 1991), eftersom vi hela tiden är del av olika sammanhang och därmed i större utsträckning blir tvungna att visa vilka vi är. I det post-traditio- 
nella samhället bygger sociala relationer och identiteter i större utsträckning än tidigare på förhandlingar. Det innebär att individernas förmåga att kunna kommunicera, speciellt samtala och förhandla innebörder, blir allt viktigare - inte minst i kontakten med företrädare för den offentliga sektorn. Ord som "möte", "samtal " och "dialog" anses ofta som positiva i sig och är knutna till föreställningar om jämlikhet - även om många forskare menar att det ofta är makt och dominans som karakteriserar mänskliga samtal, snarare än jämlikhet (Luckmann, 1990).

Dessa tendenser visar sig exempelvis i att under 1990-talet har, parallellt med en nedskärning i välfärdssystemen, förändringar av de statliga regleringarna strävat efter att göra medborgarna mer delaktiga i välfärdssystemet, vilket tagit sig uttryck i till exempel idén om brukarinflytande. Brukarinflytande syftar till att göra de medborgare som nyttjar tjänster inom olika sektorer till aktörer. I detta ljus är det rimligt att hävda att de mer övergripande förändringar som skett av olika medborgarroller, som också visar sig i nya former av terminologier som "kunder", "brukare», och i relationen mellan stat och medborgare i allmänhet, innebär att samtalet som kommunikativ form har kommit att få en ökad roll i möten mellan stat och livsvärld.

Det är alltså rimligt att hävda att människors ökade delaktighet i olika kontexter sammantaget med ett ökat individuellt ansvar för sitt livsprojekt, leder till nya former av problemhanteringsprocesser och därmed till nya relationer mellan expertsystem och klienter/brukare, där kommu- nikationen i vid bemärkelse och speciellt samtalet, får en ökad betydelse.

Med utgångspunkt i Habermas (1987) distinktion mellan systemvärld - i form av stat och marknad - och livsvärld, så är det rimligt att argumentera för att en viktig typ av reflexiva kontexter skapas i gränssnittet mellan livsvärld och systemvärld. Den engelske sociolingvisten och kommunikationsforskaren Fairclough (1992) pekar på både risker och, möjliga, positiva konsekvenser av en utveckling mot samtal som medium för myndighetskontakter. En positiv konsekvens menar han kan vara att en kommunikationsform som framförallt är hämtad från livsvärlden, det vill säga från det vardagliga småpratet och samtalet, får ökad betydelse vilket innebär att fler människor har en möjlighet att presentera sina behov och argumentera för dessa. Som en risk framhäver han att "det personliga får en ökad betydelse i offentlig myndighetsutövning och kommer att användas för rent instrumentella och strategiska syften.

Ett exempel på denna typ av "moderna» möten mellan företrädare för offentliga förvaltningar och medborgare, och där samtalandet står i centrum, är så kallade ISP-samtal. Det är möten som bygger på en arbetsmodell som kallas »Individualiserade serviceprogram» (ISP) (Sjögren, 1996) och sker inom ramarna för vissa habiliteringsverksamheter. ISP-samtal syftar till att ge funktionshindrade personer ett så kallat brukarinflytande. Det sker genom att erbjuda personer med funktionshinder och/eller deras närmast anhöriga, möjligheten att själva välja personer som skall ingå i ett team som har som mål att arbeta för personen/familjen med utgångspunkt från

Hydén, Nilholm \& Karlsson: När olikhet blir problem: Handikappforskning, kontext och social ... 
deras egna önskemål. Målet för arbetssättet sägs vara full delaktighet och jämlikhet och, ytterst, god livskvalitet. Av intresse för studier av dessa möten blir bland annat att undersöka hur problem identifieras och hanteras och hur olika livskontexter representeras och koordineras i samtalen (Hydén \& Nilholm, 1999).

Några studier visar just på fundamentala problem vad gäller koordineringen av kontexter såsom till exempel Pollner och McDonald-Wilker (1995). I denna studie beskriver forskarna hur föräldrarna till en dotter som skall börja i skolan, och av skolpersonal och barnpsykiatrisk expertis uppfattar som djupt problematisk, försöker övertyga de professionella om sin dotters kompetens. Båda parter beskriver och definierar barnets intellektuella och sociala kompetens utifrån sina olika sociala förutsättningar: de professionella utifrån sina organisatoriska, professionella och juridiska uppgifter, och föräldrarna utifrån sin vardagliga realitet och erfarenhet. Mötet mellan föräldrarna och personalen vid kliniken kommer att präglas av ett djupt ömsesidigt misstroende, vilket leder till att positionerna cementeras. Pollner och McDonald-Wilkers artikel belyser att vi i det vardagliga livet och som professionella utnyttjar en hel rad metoder och sätt för att ringa in, förstå, beskriva och tolka problematiska olikheter. Svårigheten är att de metoder som fungerar och har legitimitet $i$ ett vardagligt livsvärldssammanhang, ofta saknat relevans och bärkraft i en professionell kontext, och därmed uppkommer djupa kommunikativa och kunskapsmässiga klyftor mellan exempelvis föräldrar och professionella experter.

\section{Handikappforskning och forskning om social interaktion och kommunikation}

Vi har tidigare argumenterat för att försöka föra två forskningsområden närmare, nämligen den samhällsvetenskapligt inriktade handikappforskningen, och forskningen kring möten med fokus på social interaktion och kommunikation. Vi menar att det finns få exempel inom handikappforskningen som tagit sin utgångspunkt i ett studium av de interaktiva och kommunikativa processer varigenom diskurser, föreställningar om och innebörder hos handikapp och funktionshinder, etableras och används $i$ en situerad praktik. Forskning som är inriktad på studier av kommunikation och social interaktion - i första hand så kallad mikro-orienterad forskning som exempelvis interaktions- och samtalsforskning - har i den mån den alls berört området funktionshinder, sällan rest frågor som kan anses vara av vital och central betydelse inom handikappforskningen (med undantag för Stigma (Goffman, 1963)). Vi menar att en anledning till detta är att studierna på grund av sin mikro-orientering inte försökt kontextualisera studierna inom ramen för mer övergripande sociala förändringar.

Den etnometodologiskt inriktade forskningstraditionen är i detta sammanhang intressant eftersom den ställer frågor kring hur just sociala fenomen som exempelvis diagnoser, begrepp, föreställningar och kategorier som exempelvis handikapp, skapas i och genom organiseringen av den vardagliga, samordnade interaktionen (se exempelvis Garfinkel, 1967; Cicourel, 
1967/1995; Robillard, 1999). De sociala sammanhang som är av intresse är förstås både interaktionen i informella sfärer som familjelivet, som mötet mellan professionella och medborgare, och mellan professionella själva.

Metodologiskt kan det finnas anledning att diskutera framför allt naturalistiskt inriktade metoder som ett alternativ till kanske i första hand intervjuer, eftersom de skulle kunna bidra med material som tillåter analyser av just hur handlande $\mathrm{i}$ olika situationer uppkommer, beskrivs, definieras och tolkas av de inblandade. Därför är naturalistiska studier som bygger på etnografier och ett utnyttjande av (ljudoch bild-) inspelat material att föredra, eftersom det låter oss göra analyser av just samspel i form av både verbal och ickeverbal interaktion. I synnerhet möjligheten att kunna analysera icke-verbal kommunikation och interaktion är speciellt viktig för att undvika det biologiserande av kroppen som vi tidigare argumenterat emot.

För att ytterliggare belysa vikten av att studera kroppen som situerad i social interaktion kommer vi att presentera några interaktionistiskt inriktade studier av personer som mer eller mindre saknar verbal förmåga. Eftersom vårt argument är att kroppen är situerad och är viktig för all interaktion, vill vi tydliggöra att exemplen inte ska läsas som om det enbart i dessa fall är viktigt att betrakta kroppen som situerad och inte i andra, utan just för att de tydliggör vår ståndpunkt.

\section{Språk och interaktion}

Ett problem med många studier av möten mellan människor har varit att de mer eller mindre bygger på ett implicit antagande om att det är just den språkliga - talade och skrivna - diskursen som intar en central ställning, och att det därför i första hand är den verbala kommunikationen som skall studeras. Den språkliga diskursen utgör normen och en självklarhet för den i allt väsentligt talande och språkanvändande forskarvärlden, och därmed kommer just diskursen och dess centrala betydelse att framstå som närmast självklar. (Detta är något som framstår med tydlighet i Robillards (1999) analys av de kommunikativa och interaktionella problem som uppstår när han själv, forskaren, på grund av sjukdom förlorar sin förmåga att använda det talade språket.)

Även om det talade förstås är en viktig del av social interaktion i de flesta sammanhang, menar vi att denna fixering vid den språkliga diskursen har lett till två negativa konsekvenser. För det första kommer kroppen i bästa fall förstås som något som de språkliga yttranden kommer ur, men som inte har någon avgörande betydelse för interaktionen och kommunikationen; eller så riktas intresset mot hur kroppen representeras i diskursen, snarare än mot den kommunicerande kroppen själv. För det andra kommer personer som inte har tillgång till eller som inte fullt ut behärskar de språkligt diskursiva medlen att nedvärderas, därför att deras kommunikation utnyttjar andra kommunikativa medel som sällan observeras på sina egna villkor.

Studier av det vardagliga samspelet mellan människor med kommunikativa funktionshinder och dem som saknar

Hydén, Nilholm \& Karlsson: När olikhet blir problem: Handikappforskning, kontext och social ... 
sådana begränsningar visar att vad som kan uppfattas som meningsfull kommunikation är ytterligt beroende av den sociala kontexten och deltagarnas bakgrundskunskaper om varandra. Genom denna typ av forskning kan diskursens självklarhet och primat synliggöras och ifrågasättas, eftersom vissa personer helt saknar förmåga att använda sig av verbala, kommunikativa resurser, eller kan ha betydande svårigheter att göra det. Därmed blir det problematiskt att ta sin utgångspunkt i begrepp som diskurs eller samtal, eftersom de utesluter vissa grupper av personer. Det finns en inneboende risk för att dessa grupper med andra sätt att kommunicera, osynliggörs eller inte observeras, eller att personer med språkliga funktionshinder värderas med hjälp av fullspråkliga normer.

Den norske socialpsykologen och kommunikationsforskaren Ragnar Rommetveit (1974) har använt sig av uttrycket "negativ rationalism". Med det avser Rommetveit att vissa grupper av personer ofta beskrivs i termer av deras avvikelser från andra, "normala" grupper. Det ger en antydan om vikten av att ta sin utgångspunkt i samspelet mellan kommunicerande personer, snarare än dekontextualiserade och ensamma individer (Hydén, 2001).

Vi vill speciellt diskutera två forskare, nämligen David Goode (1994) och Charles Goodwin (1995, 2000), som i linje med detta har fokuserat sin uppmärksamhet på samspelet mellan personer som har påtagliga kommunikativa svårigheter och deltagare som saknar denna begränsning. Såväl Goodes som Goodwins studier är exempel på hur olikheter som redan identifierats som problematiska samt klassificerats och diagnosticerats, hanteras inom framförallt vardagliga kontexter.

\section{Goode och den osynliga kommunikationen}

Med hjälp av omfattande etnografiska studier och etnometodologiska analyser beskriver Goode (1994) den vardagliga interaktionen i en familj med en dotter med multipla funktionshinder, men också dotterns tillvaro i skolan. Dottern, som kallas Bianca, saknar nästan helt syn och hörsel, men kan ta sig fram genom att krypa och med vissa begränsningar öppna skåp och lådor och greppa olika föremål. Bianca saknar förmåga att såväl uttrycka som tyda formella språkliga tecken och symboler.

Föräldrarna och Bianca har dock utvecklat ett komplext men effektivt sätt att kommunicera som modern uttrycker med orden, "Bianca tells me everything». Den mänskliga kroppen som kommunikativ resurs bedömer Goode som framträdande och grundläggande för kommunikationen mellan framförallt modern och Bianca. De förlitar sig på syn- och hörselförnimmelser - Bianca dock i begränsad omfattning - känslostämningar, ansiktsuttryck, röstvariationer och gester.

Deras kommunikation bygger också på en sedan länge väl utvecklad kännedom om varandra och hemmets fysiska utformning. De kan på detta sätt etablera en intersubjektivt organiserad relation genom att utnyttja skilda kommunikativa resurser som exempelvis gemensamma rutiner och delad kunskap om hemmets rum och interiörer, det vill säga vem eller vilka och vad de är avsedda för. Det handlar dock inte enbart 
om att förstå varandra, intersubjektiviteten har också praktiska innebörder. Goode påtalar de asymmetriska men inte konflikterande perspektiv Bianca och föräldrarna antas ha på exempelvis hennes vistelse $\mathrm{i}$ det egna rummet. Bianca kan förmodas betrakta sitt rum som en plats där hon kan vara ifred medan föräldrarna kan uppfatta hennes vistelse i det egna rummet som ett tillfälle då hon under en viss tid kan lämnas utan tillsyn och de får möjlighet att ägna sig åt andra sysslor.

Bianca har kunskap om vilka emotionella reaktioner vissa föremål och aktiviteter väcker hos föräldrarna vilket hon kan utnyttja för att få den uppmärksamhet eller hjälp hon vill ha. Goode exemplifierar med ett tillfälle då modern säger att Bianca har tagit av sig sina hörapparater då hon hör den höga ton de ger ifrån sig. Detta är ett sätt som Bianca ofta använder för att tillkalla modern som blir arg och är tvungen att snabbt bege sig till Bianca eftersom hörapparaterna måste hanteras varsamt.

Kroppsliga kommunikativa resurser var också framträdande i Goodes (1994) interaktioner med en annan utvecklingsstörd flicka, Chris, född med svåra hörsel- och syn-nedsättningar och utan formellt språk. Till skillnad från Bianca bor Chris på en institution och Goode försöker förstå hur hon kan skapa sig en förståelse om omvärlden genom att samspela med henne på hennes villkor och genom att försöka bortse från "normala» sätt att tolka och bete sig. Goode upptäcker att Chris är mentalt aktiv och interagerar på ett komplext sätt. Goode ser till exempel det kompetenta i Chris' sätt att undersöka föremål med munnen trots att hon ibland kan använda dem på ett „riktigt»sätt. Hon kan till exempel skaka en skallra men roas inte särkilt länge av detta men desto längre av tungans, tändernas, läpparnas och även kindens utforskande av skallran. Genom att inte känna till det "rätta» eller "normala» sättet att använda en skallra är hon inte heller begränsad vad gäller dess användning och njutbarhet, något som institutionspersonalen bedömer som felaktigt och ler åt eller försöker hindra henne från att göra. Goode identifierar i hennes beteende något motsägelsefullt, å ena sidan kan hon anpassa omvärlden till sin kropps förutsättningar och erbjuda sig själv största möjliga njutning vilket är ett högst mänskligt drag; å andra sidan är det just detta beteende som påvisar hennes begränsade möjligheter att erfara världen som »normala» gör, nämligen med avsiktliga innebörder.

Goode relaterar sina iakttagelser av familjernas sätt att kommunicera med sina barn med skolpersonalens bedömningar av barnens kommunikativa förmågor, och därmed också deras sociala identitet. Utifrån skilda objektiva test kommer skolpersonalen fram till att barnen endast kan uttrycka tillfredsställelse och missnöje och detta enbart paralingvistiskt. Föräldrarna protesterar mot skolans tolkningar vilket av personalen betraktas som ett uttryck för föräldrarnas oförmåga att acceptera och förstå barnens "verkliga» situation. Goode diskuterar de skilda uppfattningarna i termer av konfrontationer mellan olika metodologier för att tolka och förstå både barnen och interaktionen mellan barnen och föräldrarna. Skolpersonalen och andra professionella använder sig av formella och kvantitativa bedömningsprocedurer,

Hydén, Nilholm \& Karlsson: När olikhet blir problem: Handikappforskning, kontext och social ... 
till skillnad från de informella och pragmatiska observationer och tolkningar som föräldrarna använder sig av. De tolkningar som ansågs grunda sig på objektiva bedömningar fick en legitimitet på bekostnad av föräldrarnas vardagliga och subjektiva erfarenheter.

\section{Gester som kommunikation}

Goodwins $(1995,2000)$ arbeten handlar om de sätt varigenom en man med afasi och mycket liten tillgång till verbala resurser tillsammans med familjemedlemmar och en sköterska bygger upp en fungerande kommunikation. Detta gör de med hjälp av en rad icke-verbala kommunikativa resurser som kroppsliga rörelser, intonation och sätt att strukturera frågor och svar, samt med mannens nyttjande av endast tre ord. Goodwins studier påminner om Goodes men metodologiskt analyserar han videomaterial med hjälp av konversationsanalytiska tekniker, istället för att ugå från fältanteckningar vilket Goode gjorde.

Mannen med afasi, som kallas Rob, har efter flera års rehabilitering av bland annat sin kommunikativa förmåga, bibehållit och utvecklat förmågan att använda orden "och", "ja" och "nejw. Goodwin menar att dessa tre ord utgör länkar till andra människors prat. Således kan inte Robs kommunicerande ses som en självständig och isolerad kompetens, utan som något som utgår från och är situerat i samspelet med andra människor. Detta förutsätter också att han omges av människor som betraktar honom som en kompetent samtalspartner. Goodwin konstaterar att den vardagliga interaktionen med Rob karakteriseras av försöken att förstå vad han har för önskemål eller vill ha sagt. Detta sker med honom som den centrale deltagaren som sitter inne med det rätta svaret vilket betraktas som viktigt och relevant att ta reda på.

Med hjälp av en sekvens vid frukostbordet visar Goodwin exempelvis hur Rob kan få det han vill ha trots att han till att börja med svarar såväl "jai som "neju på frågan om det är toast han vill ha. Detta sätter igång en fortsatt gissningssekvens från hustruns och sköterskans sida. Rob kan då utnyttja hustruns och sköterskans sätt att strukturera gissningssekvensen med alternativ och hans egna möjligheter att svara dubbeltydigt, med speciell intonation och även med sin blick. Det dubbeltydiga svaret indikerar att han inte vill ha toast, men att han vill att de ska fortsätta gissa på livsmedel inom kategorin »bröd«. Alternativet "toast « är således delvis rätt, medan förslag inom någon annan kategori livsmedel är helt fel. Goodwin kan också konstatera att Rob uttalar sitt "jai på ett något tvekande sätt som skiljer sig från det positiva "jai som han uttrycker när hustrun väl gissar rätt, vilket också indikerar att alternativet "toast" är delvis rätt. När hustrun gissar rätt vänder Rob sin blick mot henne, istället för mot sköterskan som samtidigt säger att hon vill peka på livsmedel som finns i kylskåpet. På så sätt kan han visa vem han svarar vja» till, när enbart ett ıja» hade kunnat tjäna som svar till de båda. Goodwin påpekar att han med detta inte vill antyda att Rob har samma kommunikativa förmågor som personer som kan tala. Men däremot ifrågasätter han de traditionella kompetensbedömningar som enbart baseras på den språkliga förmågan. 
Både Goodes och Goodwins studier pekar på problemen med att beskriva kommunikativa problem som individuella kommunikativa funktionshinder och egenskaper. Inte sällan uttrycks de kommunikativa funktionshindren i termer av brister och avvikelser från någon "normal» typ av verbal kompetens eller förmåga. Vi menar att den interaktivt och kommunikativt inriktade forskningen, och de studier som exemplifierats här, visar att kommunikativa problem måste betraktas och uppfattas som något som uppkommer och organiseras i interaktion mellan flera deltagare. Det är i det lokala och situerade samspelet som deltagarna etablerar problem, men det är också där som de kan finna olika sätt att lösa dessa. Inte minst visar studierna på kroppens centrala betydelse, inte endast som något som begränsar interaktionen, utan som en aktivt resurs som de inblandade parterna använder sig aktivt av (denna tanke återfinns hos Merleau-Ponty (1962) i hans analys av den kommunicerande kroppen). Med denna syn relativiseras innebörder av "impairments", funktionshinder och handikapp i vardagslivet utifrån de sätt som människor i interaktion hanterar vars och ens förutsättningar för deltagande

\section{Olikhet och mångfald}

Den "sociology of impariment" som Hughes och Paterson efterlyser och föreslår, menar vi måste sökas i relation till forskning inriktad mot den sociala interaktionen. Det är genom studier av kommunikationen och det sociala samspelet som det blir möjligt att situera kroppen och dess olikhet, och därmed att se »impairment» som i grunden något socialt.

Att vissa olikheter kommer att få betydelse för en människas möjligheter och sociala situation har alltmer kommit att uppmärksammas och problematiseras inom genusforskning, etnicitetsforskning, disability-studies och forskning om sociala klasser, vilket också lett till att forskningen kommit att politiseras (Anspach, 1979; Marks, 1999). Mot en sådan bakgrund har vi argumenterat för att det är viktigt att få kunskap om de sociala och kommunikativa processer varigenom mänskliga olikheter identifieras, kategoriseras och blir föremål för problemhanteringsprocesser.

Vi menar att det är riskabelt för en social handikappforskning att essensialisera kroppen i vid bemärkelse, utan kroppen bör förstås utifrån sin närvaro i social interaktion; kroppen är som något som levs, refereras till och som uttrycker. Vi har pekat på att det inom exempelvis den etnometodologiska forskningen har utarbetats metoder för att uppfatta och beskriva kroppen på detta sätt. Vi menar att detta är ett av de bidrag som mer mikro-orienterade sociala analyser kan ge till handikappforskningen.

Samtidigt har vi argumenterat för att analyser av situerad interaktion måste förstås mot bakgrund av mer övergripande samhälleliga villkor. Ett försök har gjorts att skissera framväxten av olika typer av kontexter för problemhantering. Kontext-begreppet är här viktigt eftersom allt mänskligt handlande är situerat i kontexter. Relationen mellan olika kontexter är ett forskningsproblem, snarare än något som kan tas för givet. En tendens i en del handkappforskning har varit att mer övergripande poli-

Hydén, Nilholm \& Karlsson: När olikhet blir problem: Handikappforskning, kontext och social ... 
tiska och juridiska sammanhang har fått ange utgångspunkterna för forskningen.

Vi tror att en forskning om funktionshinder och handikapp utifrån ett situerat, interaktivt perspektiv kan öka, och problematisera, kunskapen om funktionshinder och handikapp. Ett studium av olikheter, handikapp och funktionshinder, griper med nödvändighet in i en rad centrala och viktiga frågor vad gäller vår samhälleliga självförståelse. Alltså under vilka villkor människor är lika, och när människor inte längre behandlas som likvärdiga; frågor om de medborgerliga sociala och politiska rättigheterna, något som i sin tur är nära förknippat med att ha en samhällelig ställning som likvärdig medborgare; frågor om både kollektiva och individuella identiteter, och därmed frågan vem individen är i relation till sin sociala omvärld. Framför allt kommer denna forskning att handla om mångfald och gränserna för mångfalden.

\section{Referenser}

Cicourel, A. (1967/1995). The Social Organization of Juvenile Justice. New Brunswick: Transaction Publishers.

Csordas, T. J. (1994). Embodiment and experience. The existential ground of culture and self. Cambridge: Cambridge University Press.

Emerson, R. M. (1981). On Last Resorts. American Journal of Sociology, 87, 1-22.

Emerson, R. M., \& Messinger, S. L. (1977). The Micro-Politics of Trouble. Social Problems, 25, 121-134.

Fairclough, N. (1992). Discourse and Social Change. Cambridge: Polity Press.

Foucault, M. (1973). The Birth of the Clinic. New York: Vintage Books.

Garfinkel, H. (1967). Studies in Ethnomethodology. New York: Prentice Hall.

Gergen, K. J. (1991). The Saturated Self. Dilemmas of Identity in Contemporary Life. New York: Basic Books.

Giddens, A. (1991). Modernity and SelfIdentity. Self and Society in the Late Modern Age. Cambridge: Polity Press.

Goffman, E. (1963). Stigma. Notes on the Management of Spoiled Identity. Englewood Cliffs, N.J.: Prentince-Hall.

Goode, D. (1995). A World Without Words. The Social Construction of Children Born Deaf and
Blind. Philadelphia: Temple University Press.

Goodwin, C. (1995). Co-constructing meaning in conversations with an aphasic man. Research on Language and Social Interaction, 28, 233-260.

Goodwin, C. (2000). Gesture, aphasia and interaction. In D. McNeill (Ed.), Language and Gesture (pp. 84-98). New York: Cambridge University Press.

Habermas, J. (1987). The Theory of Communicative Action. Vol. 2. Lifeworld and System: A Critique of Functionalist Reason. Cambridge: Polity.

Hughes, B., \& Paterson, K. (1997). The Social Model of Disability and the Disappearing Body: towards a sociology of impairment. Disability and Society, 12, 325-340.

Hydén, L. C. (2001). Ensamhet eller tvåsamhet: om social dekontextualisering och kontextualisering. Utbildning och demokrati, 10, 11-26.

Hydén, L. C., \& Nilholm, C. (1999). Att höra brukarens röst: En studie av habiliteringssamtal som kommunikativ praktik. Arbetsrapprt nr. 1999:4. Linköpings universitet: Tema Kommunikation.

Kovarsky, D., Duchan, J., \& Maxwell, M. (Eds.). (1999). Constructing (In)Competence. Disabling Evaluations in Clinical and Social Interaction. Mahwah, N.J.: Lawrence Erlbaum Associates. 
Luckmann, T. (1990). Social communication, dialogue and conversation. In I. Marková and K. Foppa (Eds.), The Dynamics of Dialogue. Hemel Hempstead: Harvester Wheatsheaf

Marks, D. (1999). Dimensions of oppression: theorising the embodied subject. Disability and Society, 14, 611-626.

McDermott, R. P. (1993). The aquisition of a child by a learning disability. In S. Chaiklin \& J. Lave (Eds.), Understanding Practice. Perspectives on Activity and Context (pp. 269-305). New York: Cambridge University Press.

Mehan, H., Hertweck, A., \& Meihls, J. L. (1986). Handicapping the Handicapped. Decision Making in Student's Educational Careers. Stanford: Stanford University Press.

Mehan, H. (1993). Beneath the skin and between the ears: A case study in the politics of representation. In S. Chaiklin \& J. Lave (Eds.), Understanding practice. Perspectives on activity and context (pp. 241-268). New York: Cambridge University Press.

Merleau-Ponty, M. (1962). Phenomenology of Perception. London: Routledge \& Kegan Paul.
Paterson, K., \& Hughes, B. (1999). Disability Studies and Phenomenology: the carnal politics of everyday life. Disability and Society, 14, 597-610.

Pollner, M., \& McDonald-Wilker, M. (1985). The social construction of un-reality: A case study of a family's attribution of competence to a severly retarded child. Family Process, 24, 241-254.

Robillard, A. (1999). Meaning of a Disability: The Lived Experience of Paralysis. Philadelphia: Temple University Press.

Rommetveit, R. (1974). On Message Structure. A Framework for the Study of Language and Communication. New York: Wiley.

Sjögren, O. (1996). ISP - Individualiserade Service Program. Del 1 och 2. Stockholm: ISP Norden.

Söder, M. (1995). Var står forskaren? Om den sociala handikappforskningens möjligheter och begränsningar. Socialmedicinsk tidskrift, 72, 231-237.

Turner, B. S. (1992). Regulating Bodies. Essays in Medical Sociology. London: Routledge.

\section{Summary}

\section{When inequality becomes a problem: disability research, context and social interaction}

The aim of the article is to argue in favour of a social conception of impairments. In disability studies impairments are often either seen as the result of social structure or they are defined in medical terms. We argue that impairments could be seen as examples of how the human differences due to social norms and interaction are turned into social differences. We especially point to the ways in which interactional and ethnomethodological studies can contribute to a new understanding of impairments.

Hydén, Nilholm \& Karlsson: När olikhet blir problem: Handikappforskning, kontext och social ... 